\title{
Green synthesis of silver nanoparticles using marine algae Caulerpa racemosa and their antibacterial activity against some human pathogens
}

\author{
T. Kathiraven • A. Sundaramanickam • \\ N. Shanmugam $\cdot$ T. Balasubramanian
}

Received: 18 May 2014/ Accepted: 17 July 2014/Published online: 13 August 2014

(C) The Author(s) 2014. This article is published with open access at Springerlink.com

\begin{abstract}
We present the synthesis and antibacterial activity of silver nanoparticles using Caulerpa racemosa, a marine algae. Fresh C. racemosa was collected from the Gulf of Mannar, Southeast coast of India. The seaweed extract was used for the synthesis of $\mathrm{AgNO}_{3}$ at room temperature. UV-visible spectrometry study revealed surface plasmon resonance at $413 \mathrm{~nm}$. The characterization of silver nanoparticle was carried out using Fourier transform infrared spectroscopy (FT-IR), X-ray diffraction (XRD) and transmission electron microscope (TEM). FT-IR measurements revealed the possible functional groups responsible for reduction and stabilization of the nanoparticles. X-ray diffraction analysis showed that the particles were crystalline in nature with face-centered cubic geometry.TEM micrograph has shown the formation of silver nanoparticles with the size in the range of $5-25 \mathrm{~nm}$. The synthesized AgNPs have shown the best antibacterial activity against human pathogens such as Staphylococcus aureus and Proteus mirabilis. The above eco-friendly synthesis procedure of AgNPs could be easily scaled up in future for the industrial and therapeutic needs.
\end{abstract}

Keywords Silver nanoparticles - Green synthesis · Caulerpa racemosa . Antibacterial activity

T. Kathiraven · A. Sundaramanickam ( $₫)$.

T. Balasubramanian

Centre of Advance Study, Marine Biology, Faculty of Marine

Sciences, Annamalai University, Parangipettai 608 502,

Tamilnadu, India

e-mail: fish_lar@yahoo.com

N. Shanmugam

Department of Physics, Annamalai University, Annamalai Nagar 608 002, Tamilnadu, India

\section{Introduction}

Pathogenic bacteria are playing an important role in the creation of unknown diseases and the development of antibiotic resistance which are the major problems in the current scenario. The applications of nanoparticles are gaining an important function in the current scenario as they possess well-defined chemical, visual and mechanical attributes. Nanoparticles of metals are the most potential agents as they show excellent antibacterial activities due to their large surface area-to-volume ratio, which is getting up as the current interest in the researchers due to the growing microbial resistance against metal ions, antibiotics and the growth of resistant strains (Gong et al. 2007).

Antimicrobial nanoparticles offer various distinctive advantages in reducing acute toxicity, overcoming resistance, and lowering cost, when compared to conventional antibiotics (Pal et al. 2007; Weir et al. 2008). Antibiotics in the NPs form may sustain for long run than in tiny molecules (Nisizawa 1988). Physical and chemical synthesis methods, aimed at controlling the physical properties of the particles are mostly employed for the production of metal nanoparticles. Most of the methods are yet in the developmental phase and various troubles are often experienced with the stableness of the nanoparticles preparations, control of the crystals growth and aggregation of the particles (Brust 2002; Kowshik et al. 2003). Consequently, researchers working in the field of nanoparticles preparation turned their attention towards biological systems (Shiv Shankar et al. 2004). In the biosynthesis of nanoparticles, biological organisms like bacteria, fungi, actinomycetes, yeast, algae and plants were utilized as reducing agent or protective agents (Kaushik et al. 2010; Huh 2011). Biosynthetic method of nanoparticles has emerged as a simple and viable alternative to more complex chemical synthetic procedures to obtain nanomaterials. The 
rate of reduction of metal ions using biological agents is observed to be much quicker with an ambient temperature and pressure conditions (Kaushik et al. 2010).

Of all the different types of metal nanoparticles, the silver nanoparticles are playing a major role in the field of nanotechnology and nanomedicine. A number of living organisms are already well known to elaborate silver nanostructured compound such as cyanobacteria, bacteria, fungi, actinomycetes and plants such as Cinnamomum camphora (Huh and Kwon 2011), Medicago sativa (Tolaymat et al. 2010; Retchkiman-Schabesy et al. 2006), Pelargonium graveolens (Lukman et al. 2011), Avena sativa (Shankar et al. 2003), Azardirachta indica (Armendariz et al. 2004), Tamarindus indica (Shanker et al. 2004), Emblica offcinalis (Ankamwar et al. 2005), Aloe vera (Chandran et al. 2006), Coriandrum sativum (Badrinarayanan 2008), Carica papaya (Mude et al. 2009), Parthenium hysterophorus (Parashar et al. 2009), Tritium vulgare (Armendariz et al. 2009), Acanthella elongata (Inbakandan et al. 2010) and Sesuvivm potulacastrum (Nabikhan et al. 2010). Biosynthesis of silver NPs using the marine seaweed Sargassum wightii was carried out by Shanmugam et al., and they have shown that the sizes of the particles are in the range of $20 \mathrm{~nm}$ (Shanmugam et al. 2013). In our present study, we report the synthesis of AgNPs with sizes in the range of $10 \mathrm{~nm}$ using (Green algae) Caulerpa racemosa extract and also assessed their antagonistic effect against gram-positive and gram-negative bacteria.

\section{Materials and methods}

Sample collection

Green seaweed (C. racemosa) was collected from the Gulf of Mannar, Southeast coast of India. To maintain the freshness, the seaweed samples were instantly kept in a polythene bag with natural seawater.

Preparation of seaweeds extract

The samples were thoroughly washed with Milli Q water, chopped into fine pieces and then it was shade dried. Dried seaweed was ground well and made into fine powder. $1 \mathrm{~g}$ of biomass was kept in a 250-ml conical flask with $100 \mathrm{ml}$ of Milli Q water for $24 \mathrm{~h}$. Finally, the extract was filtered with Whatman No. 1 filter paper and stored it in a refrigerated temperature for further analysis.

\section{Biosynthesis of AgNPs}

For the biosynthesis of $\mathrm{Ag}$ nanoparticles $10 \mathrm{ml}$ seaweed filtrate was added in $90 \mathrm{ml}$ of $10^{-3} \mathrm{M}$ aqueous $\mathrm{AgNO}_{3}$ solutions at room temperature (Govindaraju et al. 2009). The bio-reduction of silver nitrate into silver nanoparticles can be confirmed by visual observation.

\section{Source of microorganisms}

The bacterial strains Staphylococcus aureus (ATCC 29123) and Proteus mirabilis (ATCC 25933) were obtained from American Type of Culture Collection Centre (ATCC) and were maintained in nutrient agar and LB agar medium procured from Himedia, Mumbai.

\section{Characterization of silver nanoparticles}

The reduction of metal ions was periodically monitored by visual inspection as well as by measuring the UV-Vis spectra of the solution by periodic sampling of aliquots of the aqueous component in $10 \mathrm{~mm}$ optical-path length quartz cuvette and periodically measured by Perkin Elmer double-beam spectrometer (Model LAMDA 25) operated between 200 and $800 \mathrm{~nm}$. XRD analysis was conducted with Rigaku DMAX 2200 diffractometer using monochromatic $\mathrm{CuK} \alpha$ radiation $(\lambda=0.154056 \AA)$ running at $30 \mathrm{kV}$ and $30 \mathrm{~mA}$. The scanning was done in the region of $2 \theta$ from $30^{\circ}$ to $80^{\circ}$ at $0.02^{\circ} \mathrm{min}^{-1}$. The crystalline size of the nanoparticles was calculated through the Scherrer's equation. The Fourier transform infrared (FT-IR) measurements were carried out to identify the existence of the functional groups in the synthesized silver nanoparticles. Dry powders of the biomass and Ag nanoparticles solutions were centrifuged at $10,000 \mathrm{rpm}$ for $15 \mathrm{~min}$ and the resulting suspensions were redispersed in sterile distilled water. The purified pellets were dried and ground with $\mathrm{KBr}$ and analyzed on an avatar 330 FT-IR instrument mode at a resolution of $4 \mathrm{~cm}^{-1}$. The morphology of the synthesized AgNPs was determined by high-resolution transmission electron microscopy (TEM). For TEM studies, the solution containing the nanoparticles was placed on copper grid and allowed to dry in a vacuum. The transmission electron micrographs were taken using TEM operated at an accelerating voltage of $90 \mathrm{keV}$.

Antibacterial assays (well diffusion method)

Antibacterial activity was assayed by using the agar well diffusion test technique. Muller Hinton agar medium (MHA) was prepared, the $\mathrm{pH}$ of the medium was maintained at 7.4 and then it was sterilized by autoclaving at $121{ }^{\circ} \mathrm{C}$ and $15 \mathrm{lbs}$ pressure for $15 \mathrm{~min} .20 \mathrm{ml}$ of the sterilized media was poured into sterilized petri dishes and allowed to solidify at room temperature. A sterile cotton swab is used for spreading each test microorganism from the $24 \mathrm{~h}$ inoculated broth evenly on the MHA plates and 


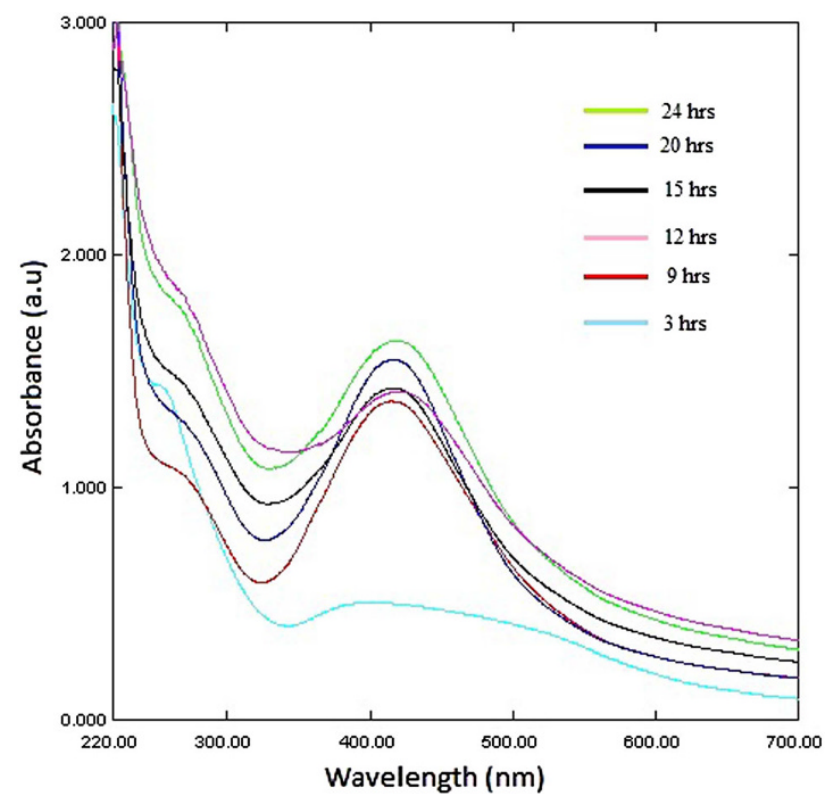

Fig. 1 Shows the UV-Vis spectra of the silver nitrate solutions incubated with marine green algae as a function of time of reaction

left for a few minutes to allow complete absorption of the inoculums. In each of these plates 5-mm diameter wells were made at the centre using an appropriate size sterilized cork borer. Different concentrations of each algal extract were added to the respective wells on the $\mathrm{MH}$ agar plates. Concentration ranges from 5, 10 and $15 \mu$, respectively, were placed in the wells and allowed to diffuse at room temperature for $30 \mathrm{~min}$. No AgNPs was added in the control plate. The AgNPs loaded plates were kept in incubation at $37{ }^{\circ} \mathrm{C}$ for $24 \mathrm{~h}$. After incubation, a clear inhibition zone around the wells indicated the presence of antimicrobial activity. All data on antimicrobial activity are the average of triplicate analyses (Nathan 1978).

\section{Results and discussion}

\section{UV-visible absorption spectrometer}

The absorption spectra of the as-prepared nanosized silver samples were characterized by UV-visible spectroscopy. The biosynthetic nanotechnology is an environmental friendly technology for the synthesis of nanoparticles. In this aspect, C. racemosa has proved to be an important biological component for the extracellular biosynthesis of stable AgNps. It is well known that $\mathrm{Ag}$ nanoparticles exhibit light yellowish to brown color. The biosynthesis of silver nanoparticles was measured by UV-Vis spectroscopy. UV-Vis spectra of the silver nitrate solutions incubated with marine green algae as a function of time of reaction.

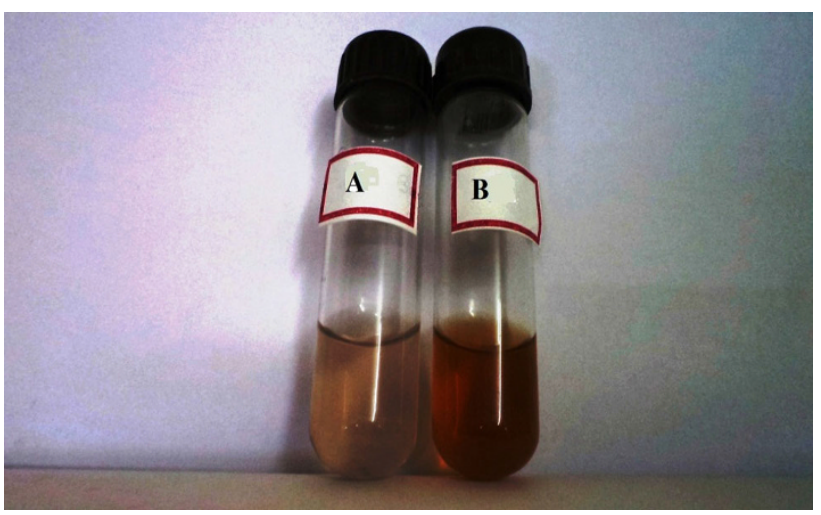

Fig. 2 Tube $(A)$ having seaweed extract and $\mathrm{Ag}^{+}$ions at the initial time $(B)$ reaction mixture after $3 \mathrm{~h}$

The surface plasmon resonance (SPR) band of nanosilver occurs initially at $440 \mathrm{~nm}(3 \mathrm{~h})$. This increases in intensity as a function of time of reaction. It is observed that the nanosilver SPR band is centered at about $413 \mathrm{~nm}$ (Fig. 1). From the spectra, it is clear that when the function of reaction time increased, the SPR band is shifted towards shorter wavelength region which shows a decrease in particle size as a result of increased band gap from the formula $E=h c / \lambda$. At lower concentrations, the SPR band is broad and it is due to large anisotropic particles. A smooth and narrow absorption band at $413 \mathrm{~nm}$ is observed which is characteristic of almost spherical nanoparticles. The position of SPR band in UV-Vis spectra is sensitive to particle shape, size, its interaction with the medium, local refractive index and the extent of charge transfer between medium and the particles (Figs. 1, 2).

Meanwhile similar studies were carried out with marine alga S. wightii (Govindaraju 2009) and plant extracts were previously obtained (Krishnaraj et al. 2010; Shrivastava 2009).

Fourier transform infrared spectroscopy (FT-IR) measurements

FT-IR spectra were recorded for $C$. racemosa extract and synthesized silver nanoparticles to identify the possible biomolecules responsible for the reduction of $\mathrm{AgNO}_{3}$ into AgNPs. FT-IR spectrum of $C$. racemosa shows different major peaks positioned at 3416, 2924, 2854, 1631, 1389, 1061,1019 and $660 \mathrm{~cm}^{-1}$ (Fig. 3). The presence of peak at $3416 \mathrm{~cm}^{-1}$ could be ascribed to O-H group in polyphenols or proteins/enzymes or polysaccharide (Song et al. 2009; Susanto et al. 2009). A small peak positioned at $2924 \mathrm{~cm}^{-1}$ may be due to $\mathrm{CH}$-stretching of alkanes. A sharp intense band observed at $1631 \mathrm{~cm}^{-1}$ can be due to the stretching vibration of the $(\mathrm{NH})=\mathrm{O}$ group. The observed band at $660 \mathrm{~cm}^{-1}$ is due to $\alpha$-glucopyranose rings deformation of carbohydrates (Feng 2000). The bands positioned at 1061 


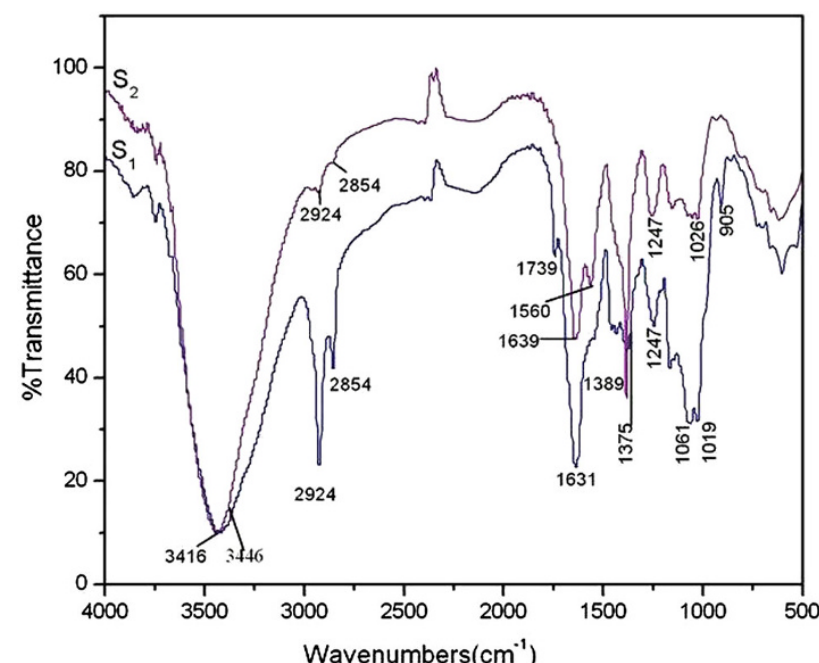

Fig. 3 Shows FT-IR spectra of (S1) C. racemosa extract (S2) biologically synthesized silver nanoparticles using Caulerpa racemosa

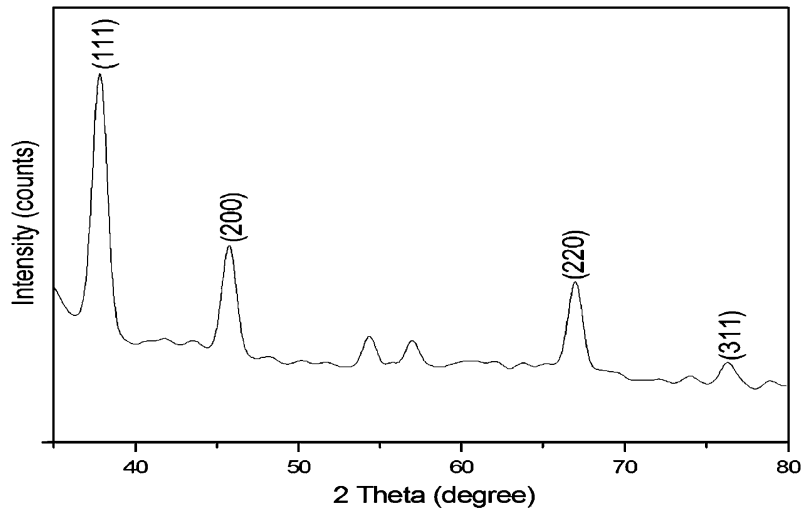

Fig. 4 Shows XRD pattern analysis of silver nanoparticles synthesized by treating $C$. racemosa extract with silver nitrate aqueous solution

and $1019 \mathrm{~cm}^{-1}$ are due to $\mathrm{C}-\mathrm{N}$ stretching vibration of aliphatic amines. On the other hand, FT-IR spectrum of the synthesized AgNPs shows the presence of major peaks at 3440 and $1639 \mathrm{~cm}^{-1}$ which are associated with $\mathrm{OH}-$ stretching vibrations and stretching vibration of the $(\mathrm{NH})=\mathrm{O}$ group, respectively. The shifting of the band from 1631 to $1639 \mathrm{~cm}^{-1}$ may be due to the binding of $(\mathrm{NH}) \mathrm{C}=\mathrm{O}$ group with the nanoparticles. The $(\mathrm{NH}) \mathrm{C}=\mathrm{O}$ groups within the case of cyclic peptides are involved in stabilizing the nanoparticles. Thus, the peptides may play an important role in the reduction of $\mathrm{AgNO}_{3}$ into $\mathrm{Ag}$ nanoparticles.

\section{XRD analysis}

The development of single-phase compound was confirmed by X-ray diffraction (XRD) method. The XRD pattern of synthesized AgNPs was observed and compared with the

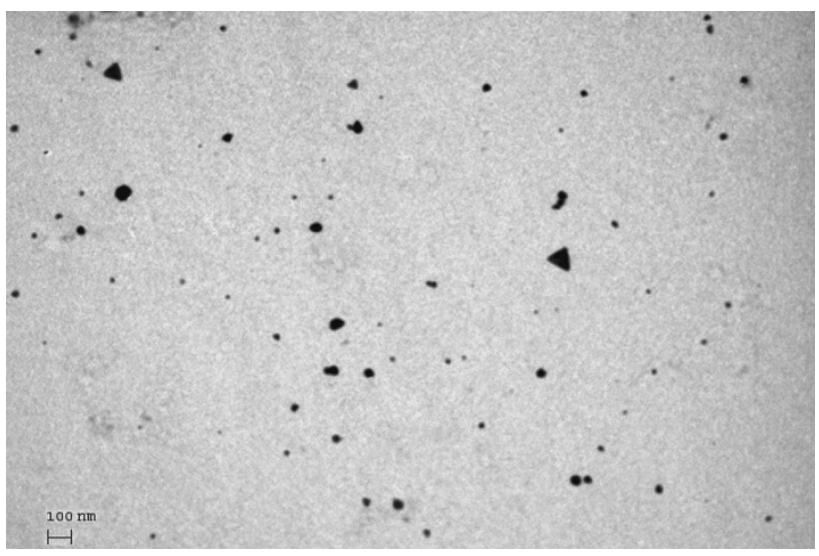

Fig. 5 TEM image silver nanoparticles $(10 \mathrm{~mL}$ of seaweed solution in $10^{-3} \mathrm{M}$ of $\mathrm{AgNO}_{3}$ in $90 \mathrm{~mL}$ of water)

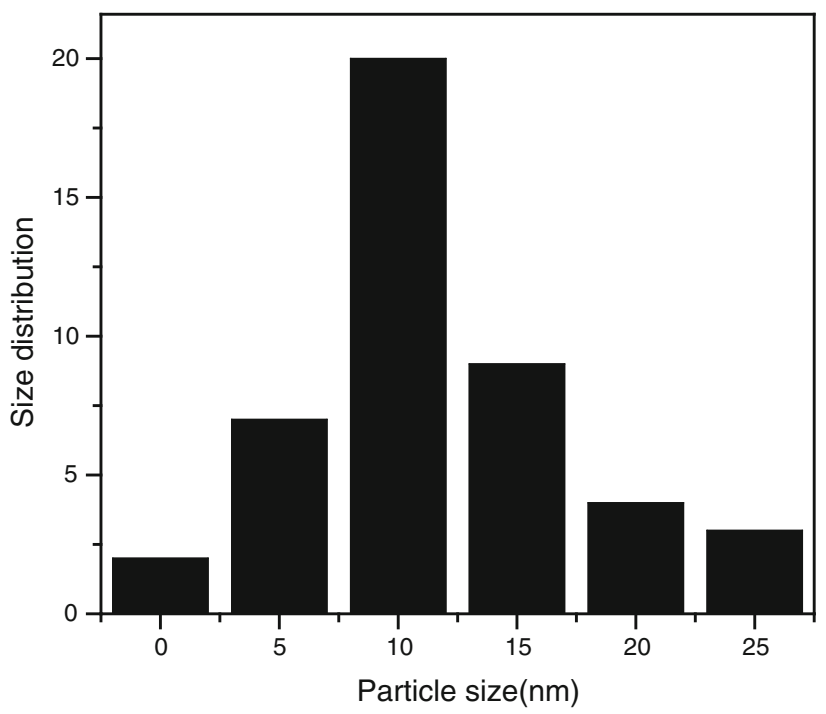

Fig. 6 Paticle size histogram of AgNPs

standard powder diffraction card of Joint Committee on Powder Diffraction Standards (JCPDS). Intense diffraction peaks due to AgNPs are clearly observed at $38.24^{\circ}$, and $44.42^{\circ}, 64.44^{\circ}$ and $77.40^{\circ}$ are pertaining to the (111) (200), (220) and (311) planes of Bragg's reflection based on the FCC (JCPDS, file No. 04-0783) structure of silver nanoparticles. No reflection peaks related to nitrate ions and other impurities were observed in this pattern, which indicating the high purity of the end product. In addition, the acquired reflections are sharp with good intensity which confirms that the structures of synthesized nanoparticles are well crystalline (Fig. 4). Our findings match with the reports suggest by Govindaraju et al. (2009).

\section{Morphology and size}

Transmission electron microscopy (TEM) has been used to identify the size, shape and morphology of nanoparticles. 
Table 1 Antimicrobial activity of silver nanoparticles against Staphylococcus aureus and Proteus mirabilis

\begin{tabular}{llllll}
\hline S. No & Pathogen name & \multicolumn{4}{l}{ Zone of inhibition $(\mathrm{mm})$} \\
\cline { 3 - 6 } & & Control & $5 \mu \mathrm{l}$ & $10 \mu \mathrm{l}$ & $15 \mu \mathrm{l}$ \\
\hline 1 & Staphylococcus aureus & 0 & 7 & 9 & 12 \\
2 & Proteus mirabilis & 0 & 8 & 11 & 14 \\
\hline
\end{tabular}
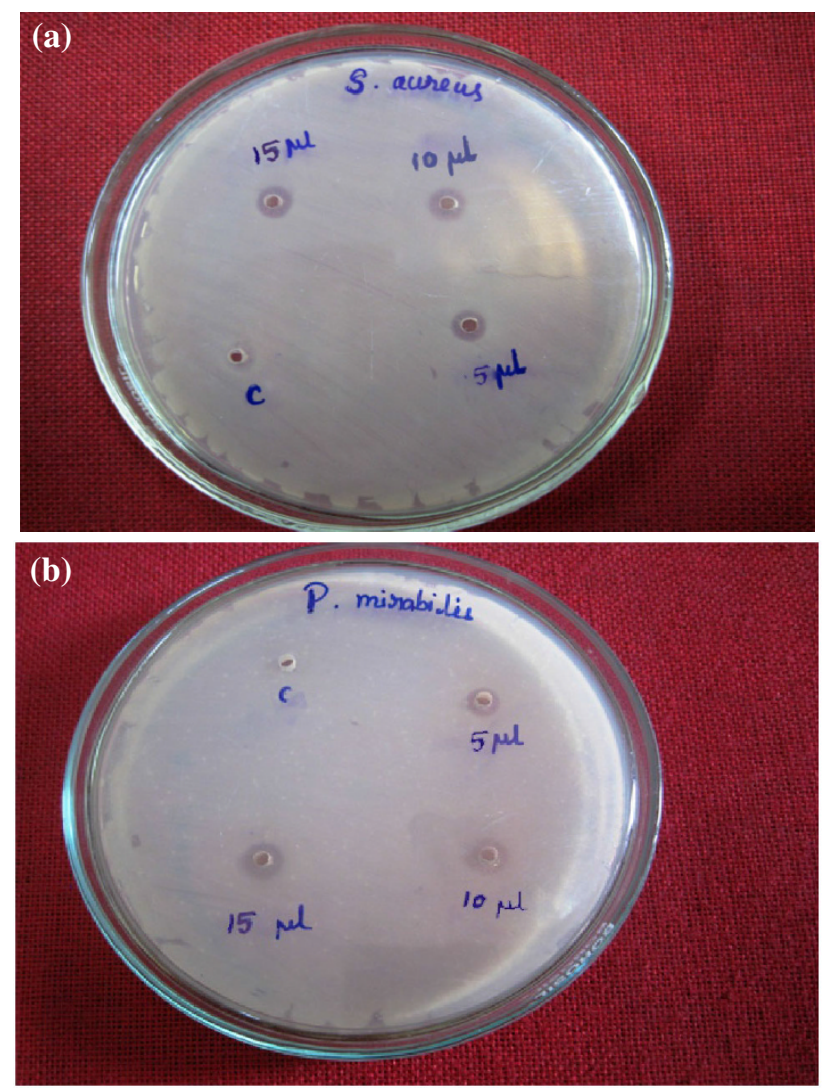

Fig. 7 Shows antibacterial activity of silver nanoparticles assayed by the agar well diffusion method in petri plates. Silver nanoparticles poured in the wells show the zone of inhibition against a Staphylococcus aureus and $\mathbf{b}$ Proteus mirabilis

From the image (Fig. 5), it is clear that the morphology of silver nanoparticles is almost spherical with few triangular nanoparticles. From the histogram analysis, it is noted that the particles with the size of $10 \mathrm{~nm}$ was more pronounced (Fig. 6).

\section{Antibacterial studies}

In the present study, the antibacterial activity of green synthesized silver nanoparticles were tested against $P$. mirabilis and $S$. aureus with various concentrations $(5,10$ and $15 \mu \mathrm{l})$ and the results are shown in Table 1 and Fig. 7. The results of antibacterial activity with a zone of inhibition maximum was found in P. mirabilis (14 $\mathrm{mm}$ for $15 \mu \mathrm{l}$ ) and minimum level antibacterial activity present in $S$. aureus $(7 \mathrm{~mm}$ for $5 \mu \mathrm{l})$. This enormous difference may be due to the susceptibility of the organism used in the current study. The nanoparticles get attached to the cell membrane and also penetrate inside the bacteria. When silver nanoparticles enter the bacterial cell, it forms a low molecular weight region in the center of the bacteria to which the bacteria conglomerates thus protecting the DNA from the silver ions. The nanoparticles preferably attack the respiratory chain cell division finally leading to cell death. The nanoparticles release silver ions in the bacterial cells, which enhance their bactericidal activity (Morones et al. 2005; Kvitek et al. 2008). Several studies propose that AgNPs may attach to the surface of the cell membrane disturbing permeability and respiration functions of the cell (Morones et al. 2005). It is also possible that AgNPs not only interact with the surface of membrane, but can also penetrate inside the bacteria (Sondi 2007).

\section{Conclusion}

It has been concluded that the extract of marine seaweed $C$. racemosa is capable of producing Ag nanoparticles extracellularly and these nanoparticles are quite stable in solution due to capping likely by the proteins present in the extract. This is an efficient, eco-friendly and simple process. The AgNPs showed potential antibacterial activity against human pathogens like $P$. mirabilis and S. aureus. Therefore, nanoparticles of silver in combination with commercially available antibiotics could be used as an antimicrobial agent after further trials on experimental animals.

Acknowledgments We thank the Ministry of Earth Sciences (MoES), New Delhi, for financial support through a scheme/ ICMAM-PD/SWQM/CASMB/35/2012. We also thank the authorities of Annamalai University for providing the necessary facilities during the entire course of this work.

Open Access This article is distributed under the terms of the Creative Commons Attribution License which permits any use, distribution, and reproduction in any medium, provided the original author(s) and the source are credited.

\section{References}

Ankamwar B, Damle C, Ahmad A, Sastry M (2005) Biosynthesis of gold and silver nanoparticles using Emblica Officinalis fruit extract, their phase transfer and transmetallation in an organic solution. J Nanosci Nanotechnol 5:1665-1671

Armendariz V, Isaac H, Jose R, Peralta V, Yacaman MJ, Troiani H, Santiago P, Jorge L, Gardea T (2004) Size controlled gold nanoparticles formation by Avena sativa biomass: use of plants in Nanobiotechnology. J Nanopart Res 6:377-379 
Armendariz V, Parsons JG, Lopez ML, Peralta-Videa JR, JoseYacaman M, Gardea-Torresdey JL (2009) Extraction of gold nanoparticles from oat and wheat biomass using sodium citrate and cetyltrimethylammonium bromide studied using XAS, HRTEM and UV-Vis. Nanotechnology 20:105607

Badrinarayanan K, Sakthivel N (2008) A simple and green method for the synthesis of silver nanoparticles using Ricinus communis leaf extract. Mater Lett 62:4588-4591

Brust M, Kiely CJ (2002) Some recent advances in nanostructure preparation from gold and silver particles: a short topical review. Colloids Surf A Physicochem Eng Aspects 202:175-186

Chandran SP, Chaudhary M, Pasricha R, Ahmad A, Sastry M (2006) Synthesis of gold nanotriangles and silver nanoparticles using Aloe vera plant extract. Biotechnol Prog 22:577-579

Feng QL, Wu J, chen GQ, cui FZ, Kim TN, Kim JO (2000) A mechanistic study of the antibacterial effect of silver ions on Escherichia coli and Staphylococcus aureus. J Biomed Mater 52(4):662-668

Gardea-Torresdey JL, Tiemann KJ, Gamez G, Dokken K, Tehuacanero S, Yacaman MJ (1999) Gold nanoparticles obtained by bioprecipitation from gold(III) solutions. J Nanopart Res 1(3):397-402

Gardea-Torresdey JL, Gomez E, Perlata-Videa JR, Parsons JG, Troiani H, Yacamen MJ (2003) Alfalfa sprouts: a natural source for the synthesis of silver nanoparticles. Langumir 19:1357-1362

Gong P, Li H, He X, Wang K, Hu J, Tan W, Zhang S, Yang X (2007) Preparation and antibacterial activity of $\mathrm{Fe}_{3} \mathrm{O}_{4} @ \mathrm{Ag}$ nanoparticles. Nanotechnology 18:604-611

Govindaraju K, Kiruthiga V, Ganesh Kumar V, Singaravelu G (2009) Extracellular synthesis of silver nanoparticles by a marine alga sargassum wightii grevilli and their antibacterial effects. J Nanosci Nanotechnol 9:1-5

Huh AJ, Kwon YJ (2011) Nanoantibiotics: a new paradigm for treating infectious diseases using nanomaterials in the antibiotics resistant era. J Control Release 156(2):128-145

Inbakandan D, Venkatesan R, Ajmal Khan S (2010) Biosynthesis of gold nanoparticles utilizing marine sponge Acanthella elongate (Dendy, 1905). Colloids Surf B 81:634-639

Kaushik N, Thakkar MS, Snehit S, Mhatre MS, Rasesh Y (2010) Biological synthesis of metallic nanoparticles. Nanomed Nanotechnol Biol Med 2:257-262

Kowshik M, Ashtaputre S, Kharrazi S, Vogel W, Urban J, Kulkarni SK (2003) Extracellular synthesis of silver nanoparticles by a silvertolerant yeast strain. MKY3. Paknikar. Nanotechnology 14:95

Krishnaraj C, Jagan EG, Rajasekar S, Selvakumar P, Kalaichelvan PT, Mohan N (2010) Synthesis of silver nanoparticles using Acalypha indica leaf extracts and its antibacterial activity against water borne pathogens. Colloids Surf B Biointerfaces 76:50-56

Kvitek L, Panacek A, Soukupova J, Kolar M, Vecerova R, Prucek R, Holecova M, Zboril R (2008) Effect of surfactants and polymers on stability and antibacterial activity of silver nanoparticles (NPs). J Phys Chem 112:5825-5834

Li S, Shen Y, Xie A, Yu X, Qiu L, Zhang L, Zhang Q (2007) Green synthesis of silver nanoparticles using Capsicum annuит L. extract. Green Chem 9:852-858

Lukman AI, Gong B, Marjo CE, Roessner U, Harris AT (2011) Facile synthesis, stabilization, and anti-bacterial performance of discrete $\mathrm{Ag}$ nanoparticles using Medicago sativa seed exudates. J Colloid Interface Sci 353:433-444

Morones JR, Elechiguerra JL, Camacho A, Ramirez JT (2005) The bactericidal effect of silver nanopartilces. Nanotechnology 16:2346-2353

Mude N, Avinash I, Aniket G, Mahendra R (2009) Synthesis of silver nanoparticles using callus extract of Carica papaya. J Plant Biochem Biotechnol 18:0971-0978
Nabikhan A, Kandasamy K, Raj A, Alikunhi NM (2010) Synthesis of antimicrobial silver nanoparticles by callus and leaf extracts from salt marsh plant, Sesuvium portulacastrum L. Colloids Surf B 79:488-493

Nathan P, Law EJ, Murphy DF, MacMillan BG (1978) A laboratory method for selection of topical antimicrobial agents to treat infected burn wounds. Burns 4:177-178

Nisizawa K, Mchaugh DJ (1988) Production and utilization of products from commercial seaweeds. FAO, Rome

Noginov MA, Zhu G, Bahoura M, Adegoke J, Small C, Ritzo BA, Drachev VP, Shalaev VM (2006) The effect of gain and absorption on surface plasmon in metal nanoparticles. Appl Phys B 86:455-460

Pal S, Tak YK, Song JM (2007) Dose the antibacterial activity of silver nanoparticles depend on the shape of the nanoparticle? A study of the gram-negative bacterium Escherichia coli. Appl Environ Microbiol 27(6):1712-1720

Parashar V, Parashar R, Sharma B, Pandey AC (2009) Parthenium leaf extract mediated synthesis of silver nanoparticles: a novel approach towards weed utilization Digest. J Nanomater Biostruct 4:723-727

Retchkiman-Schabes PS, Canizal G, Becerra-Herrera R, Zorrilla C, Liu HB, Ascencio J (2006) Biosynthesis and characterization of $\mathrm{Ti} / \mathrm{Ni}$ bimetallic nanoparticles. Opt Mater 29(1):95-98

Shankar S, Ahmad A, Sastry M (2003) Geranium leaf assisted biosynthesis of silver nanoparticles. Biotechnol Prog 19:1627-1631

Shanker SS, Rai A, Ankamwar B, Singh A, Ahmed A, Sastry M (2004) Biological synthesis of triangular gold nanoprisms. Nat Mater 3:482-488

Shanmugam N, Rajkamal P, Cholan S, Kannadasan N, Sathishkumar K, Viruthagiri G, Sundaramanickam A (2013) Biosynthesis of silver nanoparticles from the marine seaweed Sargassum wightii and their antibacterial activity against some human pathogens. Appl Nanosci 4:13204-013-0271

Shiv Shankar S, Akhilesh Rai A, Ahmad A, Sastry M (2004) Rapid synthesis of $\mathrm{Au}, \mathrm{Ag}$, and bimetallic $\mathrm{Au}$ core- $\mathrm{Ag}$ shell nanoparticles using Neem (Azadirachta indica) leaf broth. J Colloid Interface Sci 275:496-502

Shrivastava S, Dash D (2009) Applying nanotechnology to human health. J Nanotechnol 12:240-243

Sondi I, Salopek-Sondi B (2007) Silver nanoparticles antimicrobial agent: a case study on E.Coli as a model for gram negative bacteria. J Colloid Interface 275:177-182

Song HY, Ko KK, Oh LH, Lee BT (2006) Fabrication of silver nanoparticles and their antimicrobial mechanisms. Eur Cells Mater 11:58

Song JY, Jang HK, Kim BS (2009) Biological synthesis of gold nanoparticles using Magnolia kobus and Diopyros kaki leaf extracts. Process Biochem 44:1133-1138

Susanto H, Feng Y, Ulbricht M (2009) Fouling behavior of aqueous solutions of polyphenolic compounds during ultrafiltration. J Food Eng 91:333-340

Tolaymat TM, El Badawy AM, Genaidy A, Scheckel KG, Luxton TP, Suidan M (2010) An evidence-based environmental perspective of manufactured silver nanoparticle in syntheses and applications: A systematic review and critical appraisal of peerreviewed scientific papers. Sci Total Environ 408:999-1006

Weir E, Lawlor A, Whelan A, Regan F (2008) The use of nanoparticles in anti-microbial materials and their characterization. Analyst 133:835-845

Yang W, Yang C, Sun M, Yang F, Ma Y, Zhang Z, Yang X (2009) Green synthesis of nanowire-like Pt nanostructures and their catalytic properties. Talanta 78:557-564 